technique for examining the constitution of the dye-chromium complexes obtained when wool is dyed with chrome mordant dyes, and with Dr. C. B. Stevens commenced work on the kinetics of chromium dye complex formation, including a study of the rates of formation and heats of combustion of chromium complexes of a series of dyes. Dr. E. M. Hunt and Prof. F. M. Rowe completed an investigation to establish degradation processes for determining the constitution of indigoid, thioindigoid and related types of vat dyes in substance, and $\mathrm{Mr}$. F. M. Smith commenced a similar investigation of triphenylmethane dyes. Derivatives of catechol have been prepared for examination as intermediates for dyes, and Dr. A. T. Peters has completed an investigation of derivatives of $3: 4$-di-tert.-butylacenaphthene and derived indigoid dyes, and with Dr. R. J. Moualim commenced the preparation and orientation of a series of derivatives of 2-tert.-butylnaphthalene. Although the entry of British students was seriously affected by the demands of national service, the total number was fully maintained by ex-Service students and students from abroad, and the number of students in the Department of Textile Industries caused serious overcrowding.

The report of the latter Department refers to Prof. W. T. Astbury's election to the newly instituted chair of biomolecular structure, and when his work is transferred to new quarters, the Textile Physics Laboratories will be supervised by Mr. H. J. Woods, who has now been appointed lecturer in textile physics. A new scheme of work on textile finishing has been undertaken by Dr. C. S. Whewell in conjunction with Mr. C. R. Ricketts, and work on wool, rayon, jute and sisal has continued. Messrs. Courtaulds, Ltd., have now made a grant of $£ 60,000$ for building and equipping a Division of Rayon Technology within the Department. Lists of publications are included in the report.

\section{Mosquitoes and Yellow Fever in the Sudan}

DR. J. LewIs, of the Stack Medical Research Laboratories, has discussed the relationship of mosquitoes and yellow fever in the Sudan (Bull. Ent. Res., 3, pt. 4 ; 1947). It appears that most of the southern half of the Sudan is a yellow fever area in the sense that people immune to the disease have been found in many parts of that territory. The chance of the disease spreading to parts hitherto free is liable to be increased by such outbreaks as the great Nuba Mountains epidemic of 1941. It is noteworthy that several towns in the Sudan lie on import. ant air, rail and water routes leading to countries free from yellow fever. Some 140 species of mosquitoes are known from the Sudan, and, of these, twelve kinds are known to be capable of transmitting the yellow fever virus, while several other kinds are suspected in this connexion. Two further species are able to retain this virus throughout life without apparently possessing the ability to transmit the disease by their blood-sucking habits. The object of the present paper is to record information on the occurrence and distribution of mosquitoes in the Sudan. The Anophelines are only briefly considered because they are unlikely to transmit yellow fever. Among the Culicines that affect man and frequent human habitations, Aedes taylori is believed to be one of the chief vectors in the case of the Nuba Mountains epidemic. As regards Aedes cegypti, it appears that mosquito control measures have had the effect of rendering urban yellow fever epidemics, carried by this species, virtually impossible, and the disease has been exterminated from Khartoum. The relation of Taniorhynchus africanus to the disease is of special interest owing to its wide range and abundance in the Sudan. While there is no evidence that this species can act as a vector, it seems likely that it can act in this way in limited epidemics about the Upper Nile area. The author concludes by discussing the measures of mosquito control in the Sudan, which greatly restrict the possibilities of the spread of yellow fever. At the same time it is evident that the control of a rural epidemic would be difficult to achieve.

\section{University of London Appointments}

THE following appointments have been announced by the University of London: Mr. E. H. Phelps Brown, University lecturer in economics at Oxford, to the University chair of economics of labour tenable at the London School of Economics as from October 1 ; Dr. Harold Burton, senior lecturer in organic chemistry at the University of Leeds, to the University chair of chemistry tenable at King's College of Household and Social Science as from October 1; $\mathrm{Mr}$. P. T. Bauer, lecturer in economics at the London School of Economics and Political Science, to the University readership in agricultural economics tenable at the School, as from October 1; Mr. R. H. Coase, lecturer in economics at the London School of Economics and Political Science since 1938, to the University readership in economics tenable at the School as from October 1 ; Dr. P. C. C. Garnham, senior parasitologist in charge of the Division of Insect-borne Diseases in the East African Medical Service, to the University readership in medical parasitology tenable at the London School of Hygiene and Tropical Medicine; Mr. J. W. H. King, senior lecturer in civil engineering at University College, Nottingham, to the University readership in civil engineering tenable at Queen Mary College as from October 1. Dr. M. M. Loève, lecturer at Birkbeck College, to the University readership in applied mathematics tenable at Birkbeck College as from October 1; Dr. F. T. G. Prunty, lecturer in chemical pathology at St. Thomas's Hospital Medical School, to the University readership in chemical pathology tenable at the School as from October 1; Dr. Richard Rado, lecturer in mathematics in the University of Sheffield, to the University readership in pure mathematics tenable at King's College as from October 1 ; Dr. F. R. Selbie, assistant pathologist at the Bland-Sutton Institute of Pathology, to the University readership in bacteriology tenable at Middlesex Hospital Medical School as from October 1 .

The titì of professor of zoology in the University has been conferred on Dr. Alastair Graham, in respect of the post held by him at Birkbeck College; the title of professor of zoology in the University has been conferred on Dr. A. J. Grove, in respect of the post held by him at Queen Mary College; the title of reader in pure mathematics in the University has been conferred on Dr. R. G. Cooke, in respect of the post held by him at Birkbeck College; the title of reader in civil engineering in the University has been conferred on Dr. S. R. Sparkes, in respect of the post held by him at the Imperial College of Science and Technology.

The degree of doctor of science has been conferred on Prof. E. J. King, professor of pathological chemistry at the Postgraduate Medical School. 